\title{
HDL Phosphatidyl Choline and Risk-Factors of Coronary Heart Disease
}

\author{
By H. Schriewer \\ Institut für Klinische Chemie und Laboratoriumsmedizin (Zentrallaboratorium) \\ Medizinische Einrichtungen der Westfälischen Wilhelms-Universität Münster/Westfalen
}

\section{H. Schulte}

Institut für Arterioskleroseforschung an der Universität Münster, Münster/Westfalen and

\section{G. Assmann}

Institut für Klinische Chemie und Laboratoriumsmedizin (Zentrallaboratorium)

Medizinische Einrichtungen der Westfälischen Wilhelms-Universität Münster/Westfalen

(Received January 18/March 22, 1984)

Summary: As part of our epidemiological study of employees in Westphalia, the concentration of HDL phosphatidyl choline was measured in 1546 men and 778 women. The results were analysed in relation to the corresponding HDL cholesterol values, as well as the various risk factors for' coronary heart disease.

HDL phosphatidyl choline values were found to be age independent, higher in women than in men ( $p<$ 0.001 ), and lognormally distributed in both sexes (men: mean $1.162 \mathrm{mmol} / 1$, median $1.13 \mathrm{mmol} / \mathrm{l}$, minimum $0.60 \mathrm{mmol} / \mathrm{l}$, maximum $2.46 \mathrm{mmol} / \mathrm{h}$; women: mean $1.370 \mathrm{mmol} / \mathrm{l}$, median $1.34 \mathrm{mmol} / 1$, minimum 0.55 $\mathrm{mmol} / \mathrm{l}$, maximum $2.46 \mathrm{mmol} / \mathrm{l})$. A positive correlation $(\mathrm{p}<0.001)$ was found in both sexes between $\mathrm{HDL}$ phosphatidyl choline and HDL cholesterol (men: $r=0.588$; women: $r=0.605$ ).

A negative correlation was found in both sexes between HDL phosphatidyl choline values and body weight (men: $r=-0.102(p<0.001)$ women: $r=-0.129(p<0.001)$ ); and in men, but not in women, there was a negative correlation between HDL phosphatidyl choline values and triglycerides (men: $r=-0.190$ ( $p<$ 0.001 ) women: $r=-0.042$ ). A negative correlation between HDL phosphatidyl choline and cigarette smoking was found only in female smokers $(r=-0.121(\mathrm{p}<0.05))$. The correlation coefficients between HDL cholesterol and triglycerides as well as HDL cholesterol and relative body weight in both sexes were clearly higher than the corresponding correlation coefficient of $\mathrm{HDL}$ phosphatidyl choline.

In men as well as in women the HDL phosphatidyl choline/HDL cholesterol ratio decreased with increasing HDL cholesterol values or decreasing triglycerịde values in blood serum.

\section{HDL-Phosphatidylcholin und Risikofaktoren der koronaren Herzkrankheit}

Zusammenfassung: Im Rahmen unserer epidemiologischen Studie bei Betriebsangehörigen in Westfalen wurden die Konzentrationen von HDL-Phosphatidylcholin bei 1546 Männern und 778 Frauen untersucht und die Ergebnisse sowohl zu den korrespondierenden HDL-Cholesterinwerten als auch zu den verschiedenen Risikofaktoren der koronaren Herzkrankheit in Beziehung gesetzt.

HDL-Phosphatidylcholinwerte waren altersunabhängig, höher bei Frauen als bei Männern $(p<0,001)$ und bei beiden Geschlechtern lognormal verteilt (Männer: Mittelwert 1,162 mmol/, Median 1,13 mmol/1, Minimum 0,60 mmol/1, Maximum 2,46 mmol//; Frauen: Mittelwert 1,37 mmol/, Median 1,34 mmol/, Minimum $0,55 \mathrm{mmol} / \mathrm{l}$, Maximum 2,46 mmol/1). Bei beiden Geschlechtern bestand eine positive Korrelation zwischen HDL-Phosphatidylcholin und HDL-Cholesterinwerten $(p<0,001)$ (Männer: $r=0,588$; Frauen: $r=0,605$ ). 
Bei beiden Geschlechtern bestand eine negative Korrelation zwischen HDL-Phosphatidylcholinwerten und dem relativen Körpergewicht (Männer: $r=0,102(p<0,001)$, Frauen: $r=0,129(p<0,001)$ ). Bei Männern, nicht jedoch bei Frauen war eine negative Korrelation zwischen HDL-Phosphatidylcholin und Triglyceridwerten zu ermitteln (Männer: $r=0,190(p<0,001)$, Frauen: $r=0,042)$ ). Eine negative Korrelation zwischen HDL-Phosphatidylcholinwerten und Zigarettenrauchen konnte nur bei weiblichen Rauchern gezeigt werden $(r=-0,121(p<0,05))$. Die Korrelationskoeffizienten zwischen HDL-Cholesterín und Triglyceriden sowie zwischen HDL-Cholesterin und dem relativen Körpergewicht waren bei beiden Geschlechtern deutlich höher als die korrespondierenden Korrelationskoeffizienten von HDL-Phosphatidylcholin.

Sowohl bei Männern als auch bei Frauen nahm das HDL-Phosphatidylcholin/HDL-Cholesterin-Vèrhältnis mit zunehmenden HDL-Cholesterinwerten oder abnehmenden Triglyceridwerten im Blutserum ab.

\section{Introduction}

The analysis of high density lipoproteins (HDL) as a risk indicator for coronary heart disease has in recent years shown that a low HDL cholesterol level usually indicates a risk for coronary heart disease $(1-5)$. HDL are, however, not a homogenous substance but a heterogenous group of macromolecules with varying composition, varying metabolism and varying physico-chemical properties. A low HDL cholesterol level does therefore not necessarily mean a low HDL mass, or a change in other HDL components (apolipoproteins A-I, A-II, phosphatidyl choline, sphingomyelin). Several clinical studies have indicated low levels of apolipoprotein A-I in subjects with coronary heart disease $(6-8)$, but the predictive power of $\mathrm{HDL}$ apolipoproteins with respect to coronary heart disease has not been established in prospective epidemiological studies. Also the possible relationship of HDL phospholipids (phosphatidyl choline, sphingomyelin) to the risk factors for coronary heart disease has not really been fully investigated, due to the elaborate procedures for the analysis of phospholipids.

Recently, enzymatic methods have been developed in order to measure HDL phosphatidyl choline (911). In this report we present the first results of our epidemiological study on the relationship of HDL phosphatidyl choline to the various risk factors for coronary heart disease.

\section{Materials and Methods}

\section{Sample material}

As sample material we used 1546 sera from male employees and 778 sera from female employees from the "Prospective epidemiological study of company employees in Westphalia" which is reported on elsewhere (12). In this manuscript cross sectional data are reported.
The 1546 men were between 16 and 69 years old $(\bar{x}=42.0$ years, $\sigma=10.7$ years), the minimum of the Broca Index was $64 \%$, the maximum $161 \%$, the mean value $103.4 \%$ and the standard deviation $13.1 \%$. No statistically significant difference was observed between smokers (persons who at present smoke cigarettes) and non-smokers (persons who had never smoked) for age (nonsmokers: $40.8 \pm 10.5$ years, smokers: $39.9 \pm 11.1$ years) and Broca Index (non-smokers: $102.4 \% \pm 13.2 \%$, smokers: $102.0 \%$ $\pm 13.8 \%$ ), whereas men who quite smoking were signifiçantly older (45.4 \pm 9.5 years) and had a higher Broca Index (106.0\% \pm $12.0 \%)$ than smokers and non-smokers $(p<0.01)$.

The 778 women were between 17 and 67 years old $(\overline{\mathrm{x}}=37.1$ years, $\sigma=13.0$ years), their Broca Index varied from $67 \%$ to $189 \%(\bar{x}=99.2 \%, \sigma=16.8 \%)$. Female smokers $(32.3 \pm 11.5$ years) were younger than female non-smokers $(40.3 \pm 13.0$ years), or ex-smokers $(36.3 \pm 13.0$ years) $(p<0.05)$. Values of the Broca Index were observed to be significantly higher in female ex-smokers $(100.3 \% \pm 19.0 \%)$ as well as in non-smokers $(100.9$ $\pm 17.5 \%)$ compared to smokers $(96.4 \% \pm 14.6 \%)(p<0.01)$, though no significant differences were observed between the first two groups.

Lipid assays

Total cholesterol and triglycerides were analysed using a SMACAutoanalyser (Technicon, Bad Vilbel, FRG), as previously described (12).

\section{Analysis of $\mathrm{HDL}$ components}

$\mathrm{HDL}$ components were analysed in the supernatant after precipitation of apolipoprotein B-containing lipoproteins with phosphotungstic acid/ $\mathrm{MgCl}_{2}$, using the Boehringer Mannheim test (test no. 400971) (13).

\section{HDL cholesterol}

HDL cholesterol was enzymatically analysed using the CHODPAP method (Boehringer Mannheim, test combination no. 187313) (14).

\section{HDL phosphatidyl choline}

Determination of HDL phosphatidyl choline was carried out as enzymatic colour test using the centrifugal analyser Cobas Bio (Hoffmann La Roche). This method is described in detail elsewhere (10).

LDL cholesterol

LDL cholesterol was calculated using the Friedewald formula (15). 


\section{Statistics}

Multiple comparisons were done by the nonparametric test of Nemenyi. For bivariate correlation analysis the Spearman rankorder correlation coefficients were computed except for cigarette consumption where Kendall's tau was used because of the large number of tied ranks. In the multiple regression model the dependent variable was logarithmically transformed, involving the assumption that the effects are multiplicative rather than additive.

The level of significance is set to 0.05 .

Results are expressed as mean \pm S.D.

\section{Results}

Distribution of HDL phosphatidyl choline values in normal individuals

Figure 1 shows the HDL phosphatidyl choline values in 1546 male and 778 female company employees in Westphalia. The values for both sexes were log-normally distributed with a difference of $+0.03 \mathrm{mmol} / 1$ between mean and median. The values for women were about $18 \%$ higher than the values for men $(\mathrm{p}<$ 0.001 ). No correlation was found between HDL phosphatidyl choline and age in either sex.

Correlation of HDL phosphatidyl choline and atherogenic risk factors

Correlation data of HDL phosphatidyl choline to various risk factors for coronary heart disease are given in table 1. A negative correlation was found in both sexes between HDL phosphatidyl choline and relative body weight (men: $\mathrm{r}=-0.102, \mathrm{p}<0.001$; women: $r=-0.129, p<0.001)$. Furthermore, in

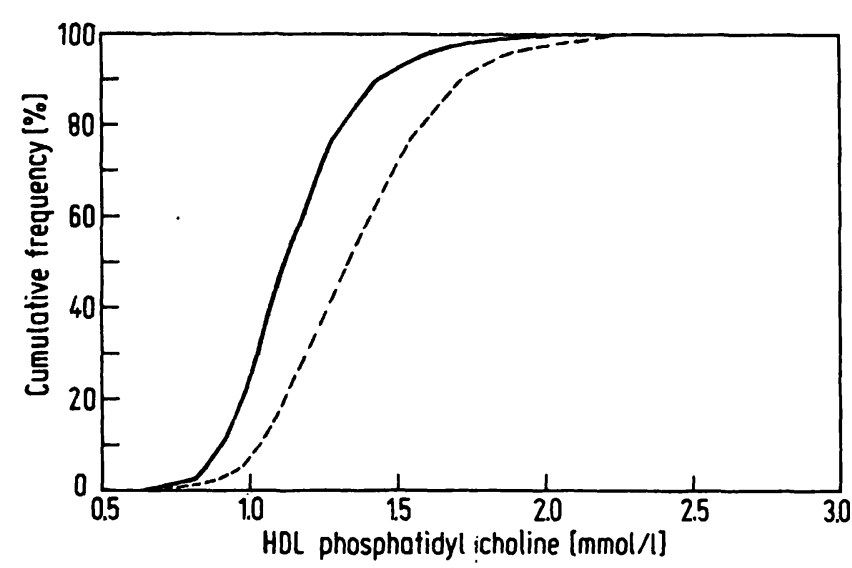

Fig. 1. HDL phosphatidyl choline values ( $\mathrm{mmol} / \mathrm{l})$ in normal individuals $(15-65$ years $)-=\operatorname{men}(n=1546)---=$ women $(n=778)$. Epidemiological study of employees in Westphalia - cross sectional data.

both sexes a positive correlation was found between HDL phosphatidyl choline and HDL cholesterol values (men: $r=0.588, p<0.001$; women: $r=$ $0.605, p<0.001)$ as well as between HDL phosphatidyl choline and total cholesterol (men: $r=0.081, p$ $<0.001$; women: $r=0.099, p<0.01$ ). Also in men, but not in women, a negative correlation was found between HDL phosphatidyl choline and triglycerides $(\mathrm{r}=-0.190, \mathrm{p}<0.001)$, while in women, but not in men, a negative correlation between HDL phosphatidyl choline and LDL cholesterol values was calculated $(r=-0.103, p<0.001)$. In female smokers a negative correlation was found between HDL phosphatidyl choline and cigarette consumption $(\mathrm{r}=$ $-0.087, \mathrm{p}<0.05$ ).

Tab. 1. Correlation coefficients between HDL phosphatidyl choline and risk factors for atherosclerosis or HDL cholesterol and risk factors for atherosclerosis, respectively.

\begin{tabular}{|c|c|c|c|c|}
\hline & \multicolumn{2}{|c|}{ HDL phosphatidyl choline } & \multicolumn{2}{|c|}{ HDL cholesterol } \\
\hline & Mèn & Women & Men & Women \\
\hline & $\mathrm{n}=1546$ & $\mathrm{n}=778$ & $\mathrm{n}=1546$ & $\mathrm{n}=778$ \\
\hline Age & $\cdot 0.0019$ & 0.0662 & -0.024 & 0.0522 \\
\hline Relative body weight (Broca Index) & $-0.10 .15^{+++}$ & $0.1291^{+++}$ & $-0.1945^{+++}$ & $-0.2213^{+++}$ \\
\hline Systolic blood pressure & -0.0291 & 0.0304 & -0.0342 & -0.0241 \\
\hline Diastolic blood pressure & -0.0492 & 0.0142 & $-0.0556^{+}$ & -0.0459 \\
\hline HDL cholesterol & $0.5878^{+++}$ & $0.6054^{+++}$ & - & - \\
\hline HDL phosphatidyl choline & - & - & $0.5878^{+++}$ & $0.6045^{+++}$ \\
\hline LDL cholesterol & $0: 0022$ & $-0.1032^{++}$ & -0.0015 & $-0.1075^{++}$ \\
\hline Triglycerides & $-0.1898^{+++}$ & -0.0420 & $-0.4404^{+++}$ & $-0.2504^{+++}$ \\
\hline Cholesterol & $0.0808^{+++}$ & $0.0991^{++}$ & $0.0827^{+++}$ & $0.1640^{+++}$ \\
\hline Cigarette consumption (only smokers) & $\begin{array}{l}-0.0055 \\
(n=469)\end{array}$ & $\begin{array}{l}-0.0873^{+} \\
(\mathrm{n}=271)\end{array}$ & $\begin{array}{l}-0.0755^{+} \\
(n=469)\end{array}$ & $\begin{array}{c}0.0142 \\
(n=271)\end{array}$ \\
\hline
\end{tabular}

\footnotetext{
$+=p<0.05$

${ }^{++}=\mathrm{p}<0.01$

$+++=p<0.001$
} 
Neither male nor female smokers proved to have altered HDL phosphatidyl choline values when compared with non-smokers (persons who had never smoked) or ex-smokers (persons who had in the past been smokers but were now non-smokers).

In a multiple regression model the negative correlation found in both sexes between HDL phosphatidyl choline and relative body weight even vanished when age, cigarette consumption, systolic and diastolic blood pressure, HDL cholesterol, triglycerides and cholesterol were taken into account, while the other correlations remained statistically significant (tab. 2).
For comparison we also calculated the correlation coefficients between the corresponding HDL cholesterol values and the various risk factors (tab. 1). In both sexes the correlation coefficients between total cholesterol and HDL cholesterol (men: $r=0.083$, $p$ $<0.001$, women: $\left.\mathrm{r}=0.164, \mathrm{p}=^{\prime}<0.001\right)$ and between total cholesterol and HDL phosphatidyl choline (see above) were comparable, while those between HDL cholesterol and triglycerides (men: $r=$ $-0.440, \mathrm{p}<0.001$; women: $\mathrm{r}=-0.250, \mathrm{p}<$ 0.001 ), as well as $\mathrm{HDL}$ cholesterol and relative body weight (men: $\mathrm{r}=-0.195, \mathrm{p}<0.001$, women: $\mathrm{r}=$ $-0.221, p<0.001$ ) were clearly higher than the corresponding correlation coefficients between HDL phosphatidyl choline and the risk factors mentioned.

Tab. 2. Standardized multiple regression coefficients of log HDL phosphatidyl choline and log HDL cholesterol on risk factors for atherosclerosis.

\begin{tabular}{llccc}
\hline & \multicolumn{2}{l}{ HDL phosphatidyl choline } & \multicolumn{2}{l}{ HDL cholesterol } \\
& Men & Women & Men & Women \\
& $\mathrm{n}=1546$ & $\mathrm{n}=778$ & $\mathrm{n}=1546$ & $\mathrm{n}=778$ \\
\hline Age & 0.00379 & 0.06470 & -0.01770 & -0.02343 \\
Relative body weight (Broca Index) & 0.00674 & -0.05855 & $-0.10161^{+++}$ & $-0.16217^{+++}$ \\
Systolic blood pressure & 0.00930 & -0.01790 & 0.00101 & 0.06490 \\
Diastolic blood pressure & -0.03127 & 0.0492 & -0.03655 \\
HDL cholesterol & $0.60134^{+++}$ & $0.66072^{+++}$ & - & - \\
HDL phosphatidyl choline & - & - & $0.50316^{+++}$ & $0.55603^{+++}$ \\
Triglycerides & $-0.06996^{++}$ & $-0.07198^{+}$ & $-0.34891^{+++}$ & $-0.32542^{+++}$ \\
Cholesterol & $0.04530^{+}$ & $0.012776^{+++}$ & $0.19529^{+++}$ & $0.25653^{+++}$ \\
Cigarette consumption & 0.00255 & $-0.07334^{+}$ & $-0.08232^{+++}$ & -0.01072 \\
\hline
\end{tabular}

$+=p<0.05$

$++=p<0.01$

${ }^{+++}=\mathrm{p}<0.001$

Tab. 3. HDL phosphatidyl choline / HDL cholesterol ratio in relation to HDL cholesterol and triglycerides in males. Epidemiological study in company employees in Westphalia - cross sectional data.

\begin{tabular}{|c|c|c|c|c|}
\hline & \multicolumn{4}{|l|}{ Men } \\
\hline & $\begin{array}{l}\text { HDL cholesterol } \\
<0.907 \mathrm{mmol} / 1\end{array}$ & $\begin{array}{l}\text { HDL cholesterol } \\
0.907-1.400 \mathrm{mmol} / \mathrm{l}\end{array}$ & $\begin{array}{l}\text { HDL cholesterol } \\
>1.400 \mathrm{mmol} / 1\end{array}$ & Total group \\
\hline Triglycerides $<1.71 \mathrm{mmol} / 1$ & $\begin{array}{l}1.184+0.157 \\
\mathrm{n}=79\end{array}$ & $\begin{array}{l}1.003+0.160 \\
n=731\end{array}$ & $\begin{array}{l}0.863+0.155 \\
n=204\end{array}$ & $\begin{array}{l}0.989+0.177 \\
n=1014\end{array}$ \\
\hline \multirow[t]{3}{*}{ Triglycerides $\geq 2.28 \mathrm{mmol} / \mathrm{l}$} & $\begin{array}{l}1.278^{\circ}+0.204 \\
n=98\end{array}$ & $\begin{array}{l}1.093^{* *}+0.193 \\
n=169\end{array}$ & $\begin{array}{l}0.902+0.273 \\
\mathrm{n}=14\end{array}$ & $\begin{array}{l}1.148^{\circ *}+0.266 \\
n=281\end{array}$ \\
\hline & \multicolumn{4}{|l|}{ Women } \\
\hline & $\begin{array}{l}\text { HDL cholesterol } \\
<1.166 \mathrm{mmol} / 1\end{array}$ & $\begin{array}{l}\text { HDL cholesterol } \\
1.166-1.660 \mathrm{mmol} / \mathrm{l}\end{array}$ & $\begin{array}{l}\text { HDL cholesterol } \\
>1.660 \mathrm{mmol} / \mathrm{l}\end{array}$ & Total group \\
\hline Triglycerides $<1.71 \mathrm{mmol} / \mathrm{l}$ & $\begin{array}{l}1.132+0.221 \\
\mathrm{n}=100\end{array}$ & $\begin{array}{l}0.946+0.153 \\
\mathrm{n}=390\end{array}$ & $\begin{array}{l}0.850+0.142 \\
n=192\end{array}$ & $\begin{array}{l}0.964+0.184 \\
n=682\end{array}$ \\
\hline Triglycerides $\geq 2.28 \mathrm{mmol} / \mathrm{l}$ & $\begin{array}{l}1.241+0.179 \\
n=18\end{array}$ & $\begin{array}{l}1.168^{\circ}+0.116 \\
n=6\end{array}$ & $\begin{array}{l}0.933+0.081 \\
n=3\end{array}$ & $\begin{array}{l}1.173^{* *}+0.179 \\
n=27\end{array}$ \\
\hline
\end{tabular}


HDL phosphatidyl choline / HDL cholesterol ratio

In both sexes the HDL phosphatidyl choline / HDL cholesterol ratio was not constant but decreased with increasing HDL cholesterol values (fig. 2). In individuals with low HDL cholesterol values (men $<0.907 \mathrm{mmol} /$, women $<1.166 \mathrm{mmol} / \mathrm{l}$ ) a relative high HDL phosphatidyl choline /HDL cholesterol ratio was observed (men: $1.227 \pm 0.186, \mathrm{n}=237$; women: $1.193 \pm 0.209, \mathrm{n}=142)$, while in individuals with high HDL cholesterol values (men $>1.400$ $\mathrm{mmol} / \mathrm{\Lambda}$, women $>1.660 \mathrm{mmol} / \mathrm{l}$ ) a relatively low HDL phosphatidyl choline / HDL cholesterol ratio was obtained (men: $0.858 \pm 0.165, \mathrm{n}=239, \mathrm{p}<$ 0.001, women: $0.851 \pm 0.142, \mathrm{n}=204, \mathrm{p}<0.001$ ). Furthermore, in both sexes the HDL phosphatidyl choline / HDL cholesterol ratio increased with increasing triglycerides (tab. 3). In males, different HDL phosphatidyl choline / HDL cholesterol ratios were observed between individuals with low triglycerides $(<1.71 \mathrm{mmol} / \mathrm{l})$ and high triglycerides $(\geq 2.28$ $\mathrm{mmol} / \mathrm{l})$ in the total collective $(\mathrm{p}<0.001)$, as well as in the partial collective with low HDL cholesterol levels $(<0.907 \mathrm{mmol} / \mathrm{l})(\mathrm{p}<0.01)$ and normal HDL cholesterol levels $(0.907-1.400 \mathrm{mmol} / \mathrm{l})(\mathrm{p}<$ 0.001). In females, different HDL phosphatidyl choline / HDL cholesterol ratios between individuals with low triglycerides $(<1.71 \mathrm{mmol} / \mathrm{l})$ and high triglycerides $(\geq 2.28 \mathrm{mmol} / \mathrm{l})$ were observed in the total collective $(p<0.001)$ and in the partial collective with normal HDL cholesterol levels (1.166-1.660 $\mathrm{mmol} / \mathrm{l})(\mathrm{p}<0.01)$.

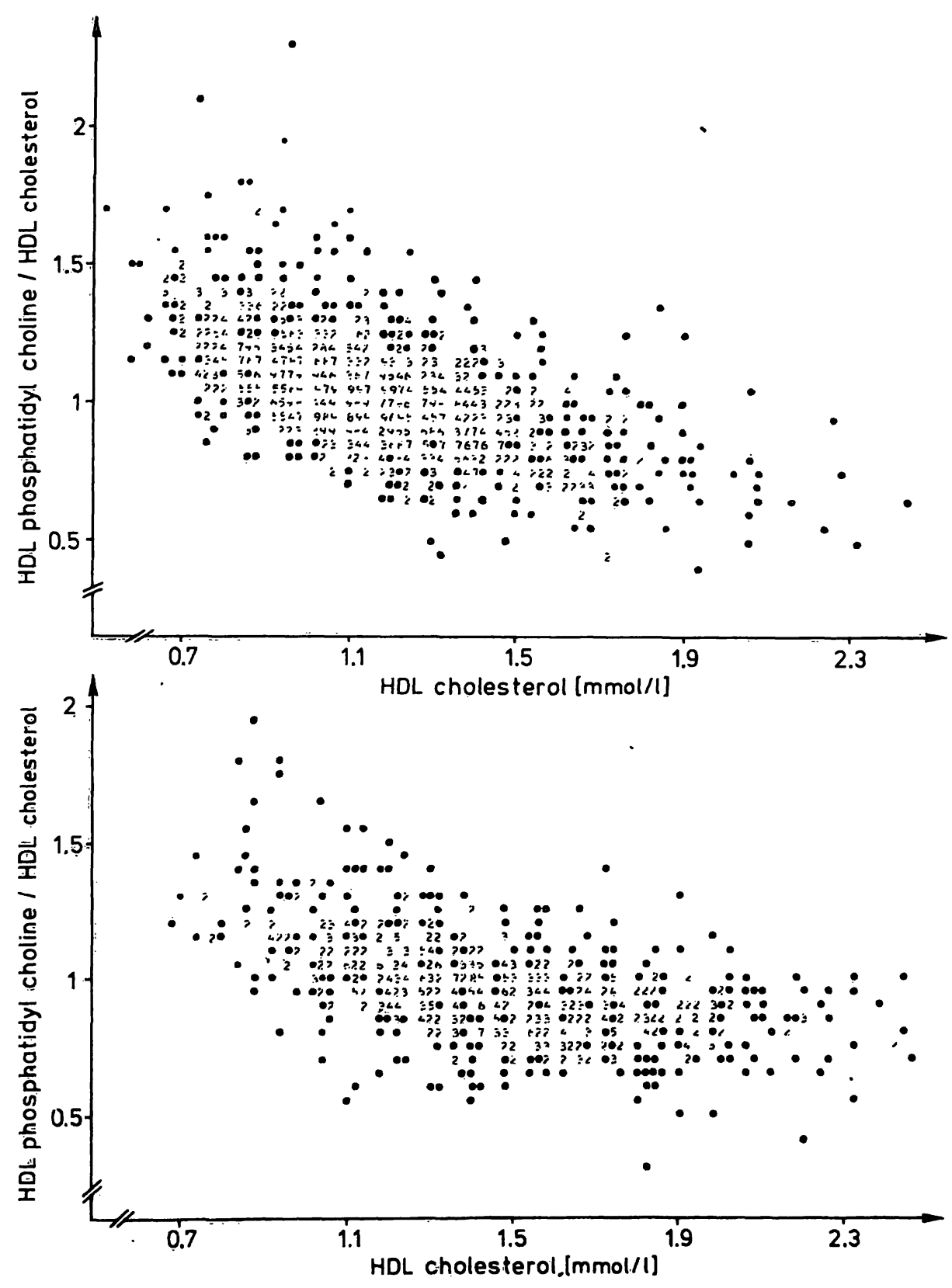

Fig. 2. HDL phosphatidyl choline/HDL cholesterol ratio in relation to HDL cholesterol in males (upper part) and in females (lower part) Epidemiological study in employees in Westphalia. 


\section{Discussion}

The determination of HDL phospholipids (phosphatidyl choline, sphingomyelin) is, unlike the determination of HDL cholesterol, not a routine method as yet. This is due to the elaborate nature of the analysis of phospholipids. Since the introduction of commercially available phospholipases and the development of sensitive methods for choline assay, it is now possible to analyse phospholipid fractions as routine parameters. We have recently developed corresponding procedures for the analysis of HDL sphingomyeline (16) and HDL phosphatidyl choline (9, $10)$. For the HDL phosphatidyl choline analysis in this study we employed an enzymatic colour test, using the analyser Cobas Bio (Hoffmann La Roche), as previously described (10).

The results presented here show a clear correlation between HDL cholesterol and HDL phosphatidyl choline. However, this correlation is not close enough to exclude variations in HDL composition. It therefore seems that the HDL phosphatidyl choline value is not a simple reflection of the HDL cholesterol value. It is noticeable that the known negative correlation between serum HDL cholesterol and serum triglycerides as well as between serum $\mathrm{HDL}$ cholesterol and relative body weight (17) is less pronounced for HDL phosphatidyl choline. Furthermore, it was interesting to note that in female smokers, but not in male smokers, a statistically significant negative correlation between HDL phosphatidyl choline and cigarette consumption was observed. By contrast, in men, the well established negative correlation between HDL cholesterol and cigarette consumption was confirmed. We have demonstrated in our studies, for the first time, that smoking, in contrast to its lowering effect on HDL cholesterol (1820), has no effect on HDL phosphatidyl choline.

\section{References}

1. Miller, G. J. \& Miller, N. (1975) Lancet I, 16-19.

2. Rhoads, G. G., Gulbrandsen, C. L. \& Kagan, A. (1976) New Engl. J. Med. 294, 293-298.

3. Berg, K., Borresen, A. \& Dahlen, G. (1976) Lancet I, 499502.

4. Castelli, W. P., Doyle, T. J., Gordon, T., Hames, C. G., Hjortland, M. C., Hulley, S. B., Kagan, A. \& Zukel, W. J. (1977) Circulation 55, 767-772.

5. Gordon, T., Castelli, W. P., Hjortland, M. C., Kannel, W. B. \& Dawber, T. R. (1977) Ann. Int. Med. 87, 393-397.

6. Kladetzky, R. G., Assmann, G., Walgenbach, S., Tauchert, P. \& Helb, H.-D. (1980) Artery 7, 191-205.

7. Bradby, G. V. H., Valente, A. J. \& Walton, K. W. (1978) Lancet $I I, 1271-1274$.

8. Avogaro, P., Bon, G. B., Cazzalato, G., Quinzi, G. B., Sanson, A., Sparla, M., Zagetti, G. C. \& Caturelli, G. (1978) Eur. J. Clin. Invest. 8, 121-129.
It is noteworthy, that with increasing triglyceride content of the serum, the HDL cholesterol decrease was more pronounced than that of HDL phosphatidyl choline. A similar change in HDL composition in hypertriglyceridaemic individuals has also been observed during analysis of HDL sphingomyelin levels in patients with a type IV hyperlipoproteinaemia (21). In these patients the relative sphingomyelin content of HDL was clearly higher than in normotriglyceridaemic individuals (21). The reason for these observations seems to be related to the subfraction composition of $\mathrm{HDL}$ (e.g. $\mathrm{HDL}_{1}, \mathrm{HDL}_{2}, \mathrm{HDL}_{3}$ ). It is known that changes in the plasma HDL level mainly affect $\mathrm{HDL}_{2}(22)$, and that an inverse correlation of $\mathrm{HDL}_{2}$ and VLDL in plasma exists (23). Data published by various authors show that the phospholipid / cholesterol ratio of $\mathrm{HDL}_{2}$ is lower than that of $\mathrm{HDL}_{3}$ (24-27). The HDL phospholipid / HDL cholesterol ratio in serum, therefore, may well be a partial reflection of the ratio of HDL subfractions in serum. Thus, a high HDL cholesterol content corresponds to a high $\mathrm{HDL}_{2}$ concentration and a lower HDL phosphatidyl choline / HDL cholesterol ratio, whereas a low HDL cholesterol content (frequently associated with hypertriglyceridaemia) corresponds to a low $\mathrm{HDL}_{2}$ concentration and a higher HDL phosphatidyl choline / HDL cholesterol ratio. Further studies, however, are needed to evaluate to what extent the relative distribution of the HDL lipid components is a reflection of the change in the relative distribution of the HDL subfractions, and to what extent the relative distribütion of the HDL lipid components is a reflection of the change of the composition of HDL particles within each density class.

9. Schriewer, H., Jabs, H.:U., Günnewig, V. \& Assmann, G. (1983) J. Clin. Chem. Clin. Biochem. 21, 145-150.

10. Schriewer, H., Jung, G., Emke, F. \& Assmann, G. (1983) J. Clin. Chem. Clin. Biochem. 21, 611-614.

11. Blaton, V., De Buyzere, M., Spincemaille, J. \& Declercq, B. (1983) Clin. Chem. 29, 806-809.

12. Assmann, G., Oberwittler, W., Schulte, H., Schriewer, H., Funke, H., Epping, P. H. \& Hauss, W. H. (1980) Internist 2l, 446-459.

13. Assmann, G., Schriewer, H. \& Funke, H. (1981) J. Clin. Chem. Clin. Biochem. 19, 273-278.

14. Assmann, G., Schriewer, H., Schmitz, G. \& Hägele, E.-O. (1983) Clin. Chem. 29, 2026-2030.

15. Friedewald, W. T., Levy, R. I. \& Fredrickson, D. S. (1972) Clin. Chem. 18, 499-509.

16. Schriewer, H., Jabs, H.-U. \& Assmann, G. (1982) J. Clin. Chem. Clin. Biochem. 20, 305-312. 
17. Assmann, G., Schriewer, H., Schulte, H. \& Oberwittler, W. (1980) Internist $21,202-212$.

18. Dedonder-Decoopman, E., Fievet-Desreumaux, C., Campos, E., Moulin, S., Devailly, P., Sezille, G. \& Jaillard, J. (1980) Atherosclerosis 37, 559-568.

19. Garrison, R. J., Kannel, W. B., Feinbleib, M., Castelli, W. P., McNamara, P. M. \& Padgett, S. J. (1978) Atherosclerosis 30, 17-25.

20. Assmann, G., Schulte, H. \& Schriewer, H. (1984) J. Clin. Chem. Clin. Biochem. 22, 397-402.

21. Schriewer, H., Günnewig, V. \& Assmann, G. (1983) J. Clin. Chem. Clin. Biochem. 21, 139-143.

22. Anderson, D. W., Nichols, A. V., Pau, S. S. \& Lindgren, F. T. (1978) Atherosclerosis 29, 161-179.
23. Nichols, A. V. (1967) Human serum lipoproteins and their interrelationships. In: Advances in Biological and Medical Physics (Lawrence, J. H., Gofman, J. W. \& Hayes, T. L., eds.) pp. 110-158. Academic Press New York.

24. Shepherd, J., Packard, C. J., Stewart, J. M., Vallance, B. D., Veitch Lawrie, T. D. \& Morgan, H. G. (1980) Clin. Chim. Acta $101,57-62$.

25. Chapman, M. J., Goldstein, S., Lagrange, D. \& Laplaud, P. M. (1981) J. Lipid Res. 22, 339-358.

26. Taskinen, M.-R., Välimäki, M., Nikkilä, E. A., Kuusi, T., Ehnholm, Ch. \& Ylikahri, R. (1982) Metabolism 31, 11681174.

27. Avogaro, P., Cazzalato, G., Belussi, F. \& Bittolo Bon, G. (1982) Artery 10, 317-328.

Professor Dr. G. Assmann Institut für Klinische Chemic und Laboratoriumsmedizin (Zentrallaboratorium) Medizinische Einrichtungen der Westfälischen Wilhelms-Universität Albert-Schweitzer-Straße 33 D-4400 Münster 
$\therefore$ 